\title{
ANTI-INFLAMMATORY AND ANTIOXIDANT ACTIVITY OF SYNTHESIZED MANNICH BASE DERIVATIVES OF (2E,6E)-2-[(4-HYDROXY-3-METHOXYPHENYL)METHYLIDENE]-6-(PHENYL METHYLIDENE)CYCLOHEXAN-1-ONE
}

\author{
HAYUN HAYUN*, BAITHA PALANGGATAN MAGGADANI, ARINI KURNIA, AULIA HANIFAH, MEIDI YULIANDI, \\ IDA FITRIYANI, SEPTIANI PUTRI HADRIANTI
}

Laboratory of Pharmaceutical and Medicinal Chemistry, Faculty of Pharmacy, Universitas Indonesia, Depok 16424, West Java, Indonesia. Email: hayun.ms06@gmail.com

Received: 13 October 2018, Revised and Accepted: 15 November 2018

\section{ABSTRACT}

Objective: To further understand this compound, we synthesized and evaluated the antioxidant and anti-inflammatory activity of a series of its Mannich base derivatives.

Methods: We synthesized the compounds via the previously reported Mannich reaction method. Their structures were elucidated by Fouriertransform infrared, ${ }^{1} \mathrm{H}-\mathrm{NMR},{ }^{13} \mathrm{C}$-NMR, and high-resolution mass spectra. The derivatives' anti-inflammatory and antioxidant activities were tested using the inhibition of protein denaturation method and the 2,2-diphenyl-2-picrylhydrazyl free radical scavenging assay.

Results: The $\mathrm{IC}_{50}$ values for the anti-inflammatory activity of the 2,6-dimethylmorpholine, pyrrolidine, 1-methylpiperazine, and dimethylamine Mannich base derivatives $2 \mathrm{a}-\mathrm{d}$ were $10.67,10.72,37.75$, and $1.93 \mu \mathrm{M}$, respectively; for $(2 E, 6 E)-2-(\{4-h y d r o x y-3-$ methoxyphenyl $\}$ methylidene)-6(phenylmethylidene)cyclohexan-1-one (1), diclofenac sodium, and curcumin, the $\mathrm{IC}_{50}$ values were $56.29,1.52$, and $8.43 \mu \mathrm{M}$, respectively. The $\mathrm{IC}_{50}$ values for the antioxidant activity of compounds $2 \mathrm{a}-2 \mathrm{~d}$ were $229.62,57.29,280.43$, and $219.22 \mu \mathrm{M}$, respectively; for compound 1 , quercetin, and curcumin, the $\mathrm{IC}_{50}$ values were $144.22,27.28$, and $26.45 \mu \mathrm{M}$, respectively.

Conclusion: Substituting Mannich bases into (2E,6E)-2-[(4-hydroxy-3-methoxyphenyl) methylidene]-6-(phenylmethylidene)cyclohexan-1-one enhanced its anti-inflammatory activity, but lowered its antioxidant activity. Compound 2d, $(2 E, 6 E)-2-(\{3-[(d i m e t h y l a m i n o) m e t h y l]-4-h y d r o x y-5-$ methoxyphenyl\}methylidene)-6-(phenyl methylidene)cyclohexan-1-one, exhibited potent anti-inflammatory activity comparable to diclofenac sodium and four times higher than curcumin. However, further investigation of this compound's mechanism of action and toxicity is warranted.

Keywords: Asymmetrical mono-carbonyl analogs of curcumin, Mannich bases, Antiinflammatory, Antioxidant.

(C) 2019 The Authors. Published by Innovare Academic Sciences Pvt Ltd. This is an open access article under the CC BY license (http://creativecommons. org/licenses/by/4. 0/) DOI: http://dx.doi.org/10.22159/ijap.2019.v11s1.19448

\section{INTRODUCTION}

Curcumin, a phenolic compound found in Curcuma spp., exhibits a variety of biological activities, including anti-inflammatory and antioxidant activities [1]. However, because of its low solubility, low stability (both chemically and metabolically), and low bioavailability, its clinical applications have been limited [2,3]. Many curcumin analogs have been synthesized and investigated in attempts to improve its chemical properties and biological activity [4].

Several series of symmetrical monocarbonyl analogs of curcumin (MACs), containing a cyclohexanone or cyclopentanone linker between the two phenyl rings, reportedly have superior anti-inflammatory and antioxidant activity, higher chemical stability, and improved pharmacokinetic profiles compared to curcumin $[3,4]$. On the other hand, several asymmetrical MAC (AMACs) reportedly exhibit potent anti-inflammatory, antioxidant, and antitumor activities [5-8]. Finally, our group reported that, while AMACs containing a morpholine Mannich base exhibit low antioxidant activity, two compounds exhibit potent anti-inflammatory activity [9]. In particular, substituting a Mannich base (aminomethylation) into a compound can provide an important pharmacophore moiety to potentiate the compound's biological activity [10].

To understand the effect of Mannich base substitution on the biological activity of compounds, and to discover a new antioxidant and anti-inflammatory compound, we synthesized a series of Mannich base derivatives of one of the AMACs, $(2 E, 6 E)-2-[(4-h y d r o x y-3-$ methoxyphenyl)methylidene]-6-(phenylmethylidene)cyclohexan-1one, and evaluated their antioxidant and anti-inflammatory activity.

\section{MATERIALS AND METHODS}

Chemistry

Materials and general procedures

All chemicals and solvents were purchased from commercial sources (Sigma-Aldrich, St. Louis, USA; Merck, Darmstadt, Germany; and Mallinckrodt, St. Louis, USA) and used without further purification. The synthesized compounds' purity was determined by thin-layer chromatography (TLC) on silica gel $60 \mathrm{~F}_{254}$ plates (Merck, Germany). Melting points were determined via the open-ended capillary method, using the Analogue Melting Point Apparatus SMP11 (Stuart Scientific, UK), and were uncorrected. Infrared (IR) spectra were recorded on an Fourier-transform IR (FT-IR) spectrophotometer (8400S; Shimadzu, Japan); nuclear magnetic resonance spectra were recorded on an NMR spectrometer (A500a, Agilent, USA) with a DD2 console at $500 \mathrm{MHz}$ for ${ }^{1} \mathrm{H}-\mathrm{NMR}$ and $125 \mathrm{MHz}$ for ${ }^{13} \mathrm{C}-\mathrm{NMR}$, using tetramethylsilane as the internal standard and $\mathrm{CDCl}_{3}$ as the solvent for all compounds; and high-resolution mass spectra (HR-MS) were recorded with an ESI-TOF LCT Premier XE mass spectrometer (Waters Corp., USA).

Synthesis of asymmetrical monocarbonyl analogs of curcumin, (2E,6E)-2-(\{4-hydroxy-3-methoxyphenyl\}methylidene)-6(phenylmethylidene)cyclohexan-1-one (1) 


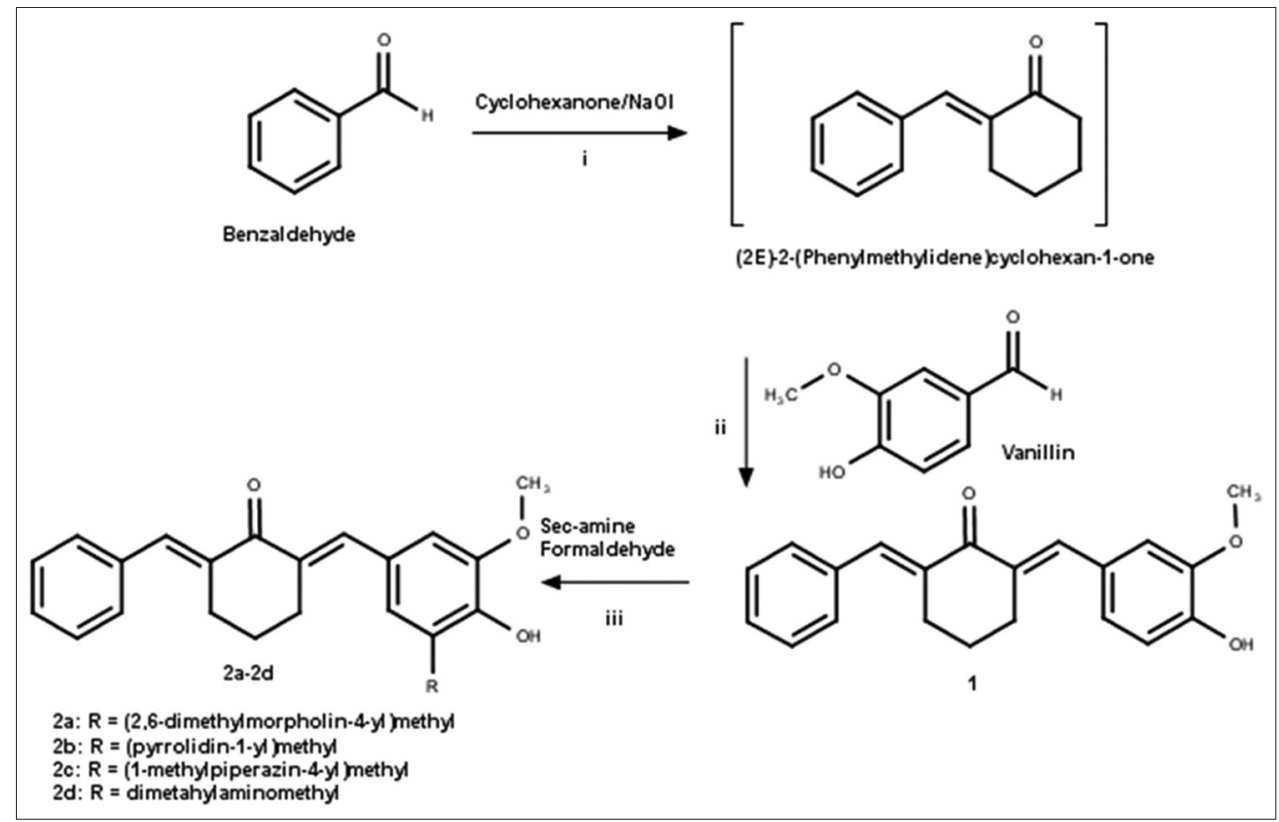

Fig. 1: Synthesis scheme for the Mannich base derivatives of (2E,6E)-2-[(4-hydroxy-3-methoxyphenyl)methylidene]-6(phenylmethylidene)cyclohexan-1-one

AMAC compound 1 was synthesized using a previously reported procedure (Fig. 1) [11].

General synthesis of Mannich bases of (2E,6E)-2-(\{4-hydroxy3-methoxyphenyl\} methylidene)-6-(phenylmethylidene)cycloh exan-1-one derivatives (2a-d)

The Mannich base derivatives of (2E,6E)-2-[(4-hydroxy-3-methoxyphenyl) methylidene]-6-(phenylmethylidene)cyclohexan-1-one (2a-d) were prepared via Mannich reactions of compound 1 using the previously reported synthesis method for morpholine Mannich base AMAC derivatives [9]. Compound 1 ( $2 \mathrm{mmol})$ was dissolved in ethanol (5 ml) and cooled in an ice bath. Then, we added a corresponding secondary amine (4 mmol) and $37 \%(\mathrm{v} / \mathrm{v})$ formaldehyde solution $(4 \mathrm{mmol})$ dropwise. The mixture was stirred for $1 \mathrm{~h}$ at room temperature (r.t.) and refluxed for 1-10 h until the reaction was deemed complete based on monitoring with TLC. The solvent was evaporated, and the residue obtained was dissolved in methanol $(50 \mathrm{ml})$ and subsequently evaporated. The resulting residue was dissolved in cooled methanol $(50 \mathrm{ml})$ by adding cooled distilled water dropwise. The colored precipitate obtained was filtered, washed with cold methanol, dried at r.t., and purified by column chromatography to obtain pure compounds $2 \mathrm{a}-\mathrm{d}$.

(2E,6E)-2-(\{4-hydroxy-3-methoxy-5-[(2,6-dimethylmorpholin4-yl)methyl]phenyl\}me-thylidene)-6-(phenylmethylidene) cyclohexan-1-one (2a)

Yellow powder, $82.4 \%$ yield, $\mathrm{mp} 108-110^{\circ} \mathrm{C}$. FT-IR $(\mathrm{KBr}) \mathrm{cm}^{-1}: 2852-$ 2933 (H-C-aliphatic), 1662 (C=0), 1573 and 1446 (C=C-aromatic),

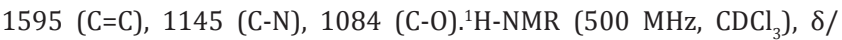
ppm: 1.17 and 1.25 (two d peaks, $6 \mathrm{H}, \mathrm{CH}_{3}-\mathrm{CH}$ two isomers of 2,6-di$\mathrm{CH}_{3}$ morpholine) [12,13], 2.71, 3.62, and 3.85 (three m peaks, $2 \mathrm{H}$, -CH-O-CH-two isomers of 2,6-di- $\mathrm{CH}_{3}$ morpholine) [12,13], $1.90\left(\mathrm{p}, \mathrm{CH}_{2}\right.$ $\mathrm{CH}_{2}-\mathrm{CH}_{2}$ cyclohexanone), 1.81 and 2.85 (two s and d peaks, $4 \mathrm{H}, \mathrm{CH}_{2}-\mathrm{N}-$ $\mathrm{CH}_{2}$ two isomers of 2,6-di- $\mathrm{CH}_{3}$ morpholine) [12,13], $2.93\left(\mathrm{t}, 4 \mathrm{H},=\mathrm{C}^{-} \mathrm{CH}_{2}-\right.$ $\mathrm{CH}_{2}$ cyclohexanone), 3.90 (s, 3H, $\left.\mathrm{CH}_{3}-\mathrm{O}-\mathrm{Ar}\right), 3.72\left(\mathrm{~s}, 2 \mathrm{H}, \mathrm{Ar}-\mathrm{CH}_{2}-\mathrm{N}\right), 4.09$ (b, 1H, OH), $6.82(1 \mathrm{H}, \mathrm{s}, \mathrm{H}-\mathrm{Ar}), 6.99(\mathrm{~s}, 1 \mathrm{H}, \mathrm{H}-\mathrm{Ar}), 7.44(\mathrm{t}, 2 \mathrm{H}, \mathrm{J}=7.4 \mathrm{~Hz}$, $\mathrm{H}-\mathrm{Ar}$ ), 7.32 (t, 1H, J=8.3 Hz, H-Ar), 7.45 (d, 2H, J=8.7 Hz, H-Ar), 7.72 and $7.79\left(\mathrm{~s}, 1 \mathrm{H}\right.$, and s, $1 \mathrm{H}, \mathrm{Ar}-\mathrm{CH}=\mathrm{C}$-ethylenic). ${ }^{13} \mathrm{C}-\mathrm{NMR}(100 \mathrm{MHz}$, $\mathrm{CDCl}_{3}$ ) $\delta$ /ppm: 19.07 (2C, 2,6-d- $\mathrm{CH}_{3}$-morpholine), 23.15 (1C, $\mathrm{CH}_{2}-\mathrm{CH}_{2}-$ $\mathrm{CH}_{2}$-cyclohexanone), 28.47 and $28.81\left(2 \mathrm{C},=\mathrm{C}^{-} \mathrm{CH}_{2}\right.$-cyclohexanone), $58.47\left(2 \mathrm{C}, \mathrm{CH}_{2}-\mathrm{N}-\mathrm{CH}_{2}\right.$-morpholine), $61.61\left(1 \mathrm{C}, \mathrm{Ar}-\mathrm{CH}_{2}-\mathrm{N}\right), 56.69$ (1C,
$\left.\mathrm{CH}_{3}-0\right)$ ) 71.78 (2C, $\mathrm{CH}_{2}-\mathrm{O}-\mathrm{CH}_{2}$-morpholine), 113.74, 120.77, 124.10, $127.30,128.59$, and 133.82 (6C, $\mathrm{C}_{\mathrm{H}}$ ), 128.47, and 130.42 (4C, $\mathrm{C}_{\mathrm{H}}$ ), 136.19, 136.39, 136.59, and 137.59 (4C, $\mathrm{C}=\mathrm{C}$-ethylenic), 147.84 (1C, CAr-0), 148.31 (1C, CAr-0), 190.18 (1C, C=0). HR ESI-MS (m/z) was $448.2421(\mathrm{M}+\mathrm{H})+$, calculated mass for $\mathrm{C}_{28} \mathrm{H}_{33} \mathrm{NO}_{4:} 448.2409$ (error: $2.67 \mathrm{ppm})$.

(2E,6E)-2-(\{4-hydroxy-3-methoxy-5-[(pyrrolidin-1-yl)methyl] phenyl\}methylidene)-6-(phenylmethylidene)cyclohexan-1-one (2b)

Dark red powder, $62.6 \%$ yield, $\mathrm{mp} 120-122^{\circ} \mathrm{C}$. FT-IR $(\mathrm{KBr}) \mathrm{cm}^{-1}: 2835-$ 2951 (H-C-aliphatic), 1716 (C=0), 1662 (C=C), 1575 and 1489 (C=Caromatic), 1269 (C-N), 1155 (C-0). ${ }^{1} \mathrm{H}-\mathrm{NMR}\left(500 \mathrm{MHz}, \mathrm{CDCl}_{3}\right.$ ), $\delta /$ ppm: $1.79\left(\mathrm{~m}, 2 \mathrm{H},-\mathrm{CH}_{2}-\mathrm{CH}_{2}-\mathrm{CH}_{2}\right.$-cyclohexanone), $1.86\left(4 \mathrm{H},-\mathrm{CH}_{2}-\mathrm{CH}_{2}-\right.$ pyrroldine), $2.69\left(\mathrm{~s}, 4 \mathrm{H},-\mathrm{CH}_{2}-\mathrm{N}-\mathrm{CH}_{2}\right.$-pyrroldine), $2.92\left(\mathrm{t}, 4 \mathrm{H},=\mathrm{C}-\mathrm{CH}_{2}-\right.$ cyclohexanone), $3.89\left(\mathrm{~s}, 3 \mathrm{H}, \mathrm{CH}_{3}-\mathrm{O}-\mathrm{Ar}\right), 3.88\left(\mathrm{~s}, 2 \mathrm{H}, \mathrm{Ar}^{-\mathrm{CH}_{2}}-\mathrm{N}\right), 6.83(1 \mathrm{H}$, s, H-Ar), 6.97 (s, 1H, H-Ar), 7.31 (t, 2H, J=7.4 Hz, H-Ar), 7.39 (t, 2H, $\mathrm{J}=8.7 \mathrm{~Hz}, \mathrm{H}-\mathrm{Ar}$ ), 7.45 (d, 1H, J=8.3 Hz, H-Ar), 7.72 and 7.78 (s, 1H, and s, $1 \mathrm{H}, \mathrm{Ar}-\mathrm{CH}=\mathrm{C}$-ethylenic) ${ }^{13} \mathrm{C}-\mathrm{NMR}\left(100 \mathrm{MHz}, \mathrm{CDCl}_{3}\right) \delta / \mathrm{ppm}: 23.14(1 \mathrm{C}$, $\mathrm{CH}_{2}-\mathrm{CH}_{2}-\mathrm{CH}_{2}$-cyclohexanone), $23.72 \quad\left(2 \mathrm{C}, \quad-\mathrm{CH}_{2}-\mathrm{CH}_{2}\right.$-pyrrolidine $)$, 28.45 and $28.78\left(2 \mathrm{C},=\mathrm{C}-\mathrm{CH}_{2}\right.$-cyclohexanone), $53.49\left(2 \mathrm{C},-\mathrm{CH}_{2}-\mathrm{N}^{-\mathrm{CH}_{2}-}\right.$ pyrrolidine), 56.09 (1C, $\left.\mathrm{Ar}-\mathrm{CH}_{2}-\mathrm{N}\right), 58.37$ (1C, $\left.\mathrm{CH}_{3}-0\right), 113.59,122.17$, $123.75,126.74,128.44$, and 137.92 (6C, CAr), 128.53, and 130.39 (4C, CAr), 133.46, 136.20, 136.42, and 137.46 (4C, C=C-ethylenic), 147.80 (1C, CAr-0), 149.05 (1C, CAr-0), 190.21 (1C, C=0). HR ESI-MS $(\mathrm{m} / \mathrm{z})$ was $404.2224(\mathrm{M}+\mathrm{H})+$, calculated mass for $\mathrm{C}_{26} \mathrm{H}_{30} \mathrm{NO}_{3}: 404.2147$ (error: $0.5 \mathrm{ppm}$ ).

(2E,6E)-2-(\{4-hydroxy-3-methoxy-5-[(1-methylpiperazin-4-yl) methyl]phenyl\}methyl-idene)-6-(phenylmethylidene)cyclohexan1-one (2c)

Orange powder, $79.5 \%$ yield, $\mathrm{mp} 128-130^{\circ} \mathrm{C}$. FT-IR $(\mathrm{KBr}) \mathrm{cm}^{-1}: 2750-$ 2931 (H-C-aliphatic), 1670 (C=0), 1531 and 1468 (C=C-aromatic), 1591 (C=C), 1261 (C-N), 1153 (C-0). ${ }^{1} \mathrm{H}-\mathrm{NMR}\left(500 \mathrm{MHz}, \mathrm{CDCl}_{3}\right), \delta /$ ppm: $1.79\left(\mathrm{~m}, 2 \mathrm{H},-\mathrm{CH}_{2}-\mathrm{CH}_{2}-\mathrm{CH}_{2}\right.$-cyclohexanone), 2.28 (s, 3H, CH3$\mathrm{N}$-piperazine), $2.58\left(\mathrm{~m}, 8 \mathrm{H},-\mathrm{CH}_{2}-\mathrm{N}-\mathrm{CH}_{2}\right.$-piperazine $), 2.92(\mathrm{t}, 4 \mathrm{H}$, $=\mathrm{C}-\mathrm{CH}_{2}$-cyclohexanone), 3.89 (s, 3H, $\left.\mathrm{CH}_{3}-\mathrm{O}-\mathrm{Ar}\right), 3.75\left(\mathrm{~s}, 2 \mathrm{H}, \mathrm{Ar}-\mathrm{CH}_{2}-\mathrm{N}\right)$, $6.81(1 \mathrm{H}, \mathrm{s}, \mathrm{H}-\mathrm{Ar}), 6.97$ (s, 1H, H-Ar), 7.31 (t, 2H, J=7.4 Hz, H-Ar), 7.38 (d, 2H, J=8.7 Hz, H-Ar), 7.44 (t, 1H, J=8.3 Hz, H-Ar), 7.70 and 7.77 (s, $1 \mathrm{H}$, and $\mathrm{s}, 1 \mathrm{H}, \mathrm{Ar}-\mathrm{CH}=\mathrm{C}$-ethylenic) $\cdot{ }^{13} \mathrm{C}-\mathrm{NMR}\left(100 \mathrm{MHz}, \mathrm{CDCl}_{3}\right) \delta /$ 
ppm: 23.13 (1C, $-\mathrm{CH}_{2}-\mathrm{CH}_{2}-\mathrm{CH}_{2}$-cyclohexanone), 28.45 and 28.79 (2C, $=\mathrm{C}-\mathrm{CH}_{2}-\mathrm{CH}_{2}$-cyclohexanone), $45.94\left(1 \mathrm{C}, \mathrm{CH}_{3}-\mathrm{N}\right.$-piperazine), 52.50 and $54.92\left(4 \mathrm{C}, \mathrm{CH}_{2}-\mathrm{N}-\mathrm{CH}_{2}\right.$-piperazine), $56.08\left(1 \mathrm{C}, \mathrm{Ar}-\mathrm{CH}_{2}-\mathrm{N}\right), 61.24(1 \mathrm{C}$, $\mathrm{CH}_{3}-0$ ), $113.75,121.11,123.99,127.10,128.44$, and 137.69 (6C, $\mathrm{CAr}$ ), 128.6, and 130.43 (4C, CAr), 133.68, 136.19, 136.40, and 136.48 (4C, C=C-ethylenic), 147.87 (1C, CAr-0), 148.22 (1C, CAr-0), 190.20 (1C, $\mathrm{C}=0)$. HR ESI-MS $(\mathrm{m} / \mathrm{z})$ was $433.2473(\mathrm{M}+\mathrm{H})+$, calculated mass for $\mathrm{C}_{27} \mathrm{H}_{33} \mathrm{~N}_{2} \mathrm{O}_{3:} 433.2413$ (error: $4.2 \mathrm{ppm}$ ).

(2E,6E)-2-(\{4-hydroxy-3-methoxy-5-(dimethylaminomethyl) phenyl\}methylidene)-6-(phenylmethylidene)cyclohexan-1-one (2d)

Brownish-orange powder, $32.49 \%$ yield, mp $102-104^{\circ} \mathrm{C}$. FT-IR (KBr) $\mathrm{cm}^{-1}$ : 2930-2992 (H-C-aliphatic), 1661 (C=0), 1559 and 1485 (C=Caromatic), 1586 (C=C), 1258 (C-N), 1159 (C-0). ${ }^{1} \mathrm{H}-\mathrm{NMR}(500 \mathrm{MHz}$, $\mathrm{CDCl}_{3}$ ), $\delta$ /ppm: $1.82\left(\mathrm{~m}, 2 \mathrm{H},-\mathrm{CH}_{2}-\mathrm{CH}_{2}-\mathrm{CH}_{2}\right.$-cyclohexanone), 2.36 (s, 6H, $\left.\mathrm{CH}_{3}-\mathrm{N}-\mathrm{CH}_{3}\right), 2.93\left(\mathrm{t}, 4 \mathrm{H},=\mathrm{C}-\mathrm{CH}_{2}\right.$-cyclohexanone), 3.91 (s, 3H, $\left.\mathrm{CH}_{3}-\mathrm{O}-\mathrm{Ar}\right)$, $3.69\left(\mathrm{~s}, 2 \mathrm{H}, \mathrm{Ar}_{-}-\mathrm{CH}_{2}-\mathrm{N}\right), 6.82(1 \mathrm{H}, \mathrm{s}, \mathrm{H}-\mathrm{Ar}), 6.98(\mathrm{~s}, 1 \mathrm{H}, \mathrm{H}-\mathrm{Ar}), 7.39(\mathrm{t}, 2 \mathrm{H}$, $\mathrm{J}=7.4 \mathrm{~Hz}, \mathrm{H}-\mathrm{Ar}), 7.45$ (d, 2H, J=8.7 Hz, H-Ar), $7.33(\mathrm{t}, 1 \mathrm{H}, \mathrm{J}=8.3 \mathrm{~Hz}, \mathrm{H}-\mathrm{Ar})$, 7.72 and 7.78 (s, $1 \mathrm{H}$, and s, $1 \mathrm{H}, \mathrm{Ar}-\mathrm{CH}=\mathrm{C}$-ethylenic) ${ }^{13} \mathrm{C}-\mathrm{NMR}(100 \mathrm{MHz}$, $\mathrm{CDCl}_{3}$ ) $\delta$ /ppm: $23.16\left(1 \mathrm{C}, \mathrm{CH}_{2}-\mathrm{CH} 2-\mathrm{CH}_{2}\right.$-cyclohexanone), 28.47 and 28.81 (2C, =C- $\mathrm{CH}_{2}$-cyclohexanone), $44.55\left(2 \mathrm{C}, \mathrm{CH}_{3}-\mathrm{N}-\mathrm{CH}_{3}\right), 56.13(1 \mathrm{C}$, $\left.\mathrm{Ar}-\mathrm{CH}_{2}-\mathrm{N}\right), 61.72\left(1 \mathrm{C}, \mathrm{CH}_{3}-\mathrm{O}\right), 113.77,121.89,124.01,126.91,128.49$, and 137.87 (6C, CAr), 128.56, and 128.46 (4C, CAr), 133.54, 130.41, 136.22, and 136.46 (4C, C=C-ethylenic), 147.83 (1C, CAr-0), 149.02 (1C, CAr-0), 190.24 (1C, C=0). HR ESI-MS (m/z) was $378.2067(\mathrm{M}-\mathrm{H})+$, calculated mass for $\mathrm{C}_{24} \mathrm{H}_{28} \mathrm{NO}_{3 .} 378.1991$ (error: $0.5 \mathrm{ppm}$ ).

\section{Anti-inflammatory activity}

The synthesized compounds (2a-d) were screened for antiinflammatory activity via the inhibition of heat-induced albumin denaturation method, previously reported by our research group, using diclofenac sodium and curcumin as the standards [9]. The reaction mixtures consisted of $0.5 \mathrm{ml}$ solutions of the standard or test compounds in methanol, in various concentrations, combined with $4.5 \mathrm{ml}$ of bovine serum albumin (BSA) solution $(0.5 \% \mathrm{w} / \mathrm{v}, \mathrm{pH} 6.3)$ prepared in Trisbuffered saline. These mixtures were heated for $10 \mathrm{~min}$ in a water bath at $70^{\circ} \mathrm{C} \pm 2$. After cooling to r.t., the mixtures' turbidity was measured in triplicate at $660 \mathrm{~nm}$ using a UV-Vis spectrophotometer (1601, Shimadzu, Japan). The control was prepared as above but without the test compounds. The percentage (\%) of inhibition was calculated using the formula:

$\%$ Inhibition $=$

(Absorbance of control-Absorbance of test compound) Absorbance of control

The test compound's capacity to inhibit denaturation was expressed as an $\mathrm{IC}_{50}$ value which was calculated by plotting the percentage inhibition against the tested compound concentration.

\section{Antioxidant activity}

The synthesized compounds (2a-d) were evaluated for antioxidant activity using the 2,2-diphenyl-2-picrylhydrazyl (DPPH) free radical scavenging method, according to a procedure reported previously, with slight modifications $[8,14]$. Quercetin and curcumin were used as the standards. A series of solutions with various concentrations of the test compounds or standards was prepared in methanol, and $0.5 \mathrm{ml}$ of each solution was added to $0.5 \mathrm{ml}$ of $50 \mu \mathrm{g} / \mathrm{ml}$ DPPH dissolved in methanol and then incubated at r.t. in the darkroom for $30 \mathrm{~min}$. The test solution absorbance was measured at $517 \mathrm{~nm}$. The series of solutions of the test compounds (no DPPH added) served as blanks because they showed slight absorbance at $517 \mathrm{~nm}$. This experiment was performed in triplicate. The percentage (\%) of inhibition was calculated using the formula:

$\%$ Inhibition=

(Absorbance before reaction Absorbance after reaction) Absorbance before reaction
The free radical scavenging capacity of each test compound was expressed as an $\mathrm{IC}_{50}$ value which was calculated by plotting the percentage inhibition against the concentration of the test compound.

\section{RESULTS AND DISCUSSION}

\section{Chemistry}

Various MACs have been synthesized in an attempt to improve the biological activity and other properties [3-8]. The recent study reported that AMACs containing a morpholine Mannich base substituted into the phenolic ring and various substituents at para position on another phenyl ring exhibited low antioxidant activity, whereas the compounds containing methoxy or fluoro substituents at the para position on another phenyl ring exhibited potent anti-inflammatory activity that was almost comparable to that of the standard, diclofenac sodium [9]. However, the synthesis and biological activity of various Mannich base AMAC derivatives have not yet been reported. In this study, a series of four novel Mannich base derivatives of $(2 E, 6 E)$-2-[(4-hydroxy-3methoxyphenyl)methylidene]-6-(phenylmethylidene)cyclohexan1-one $(2 a-d)$ was synthesized. The title compounds $(2 a-d)$ were synthesized stepwise using the methods summarized in Fig. 1. The synthesized compounds' structures were confirmed by FT-IR, ${ }^{1} \mathrm{H}-\mathrm{NMR}$, ${ }^{13} \mathrm{C}-\mathrm{NMR}$, and HR-MS

The IR spectra of these compounds showed $\mathrm{C}-\mathrm{H}$ aliphatic bands at $2750-2992 \mathrm{~cm}^{-1}$. The bands representing the $\alpha, \beta$-unsaturated carbonyl groups, $\mathrm{C}=\mathrm{C}$ aromatic or ethylenic groups, and the $\mathrm{C}-\mathrm{O}-\mathrm{C}$ or C-N-C moieties appeared between 1661-1716, 1446-1662, and $1084-1269 \mathrm{~cm}^{-1}$, respectively. The ${ }^{1} \mathrm{H}-\mathrm{NMR}$ spectra of these compounds exhibited two singlet peaks for the two ethenyl chain protons at 7.7072 and 7.77-7.79 ppm (1H), respectively, indicating the compounds' asymmetrical structures. The two methylene protons connecting the nitrogen of the corresponding amine group to the phenyl ring $(2 \mathrm{H}$, $\left.\mathrm{Ar}-\mathrm{CH}_{2}-\mathrm{N}-\right)$ and the three protons of the methoxy groups $\left(3 \mathrm{H}, \mathrm{Ar}-\mathrm{OCH}_{3}\right)$ were observed as singlets at 3.69-3.88 and 3.89-3.91 ppm, respectively. The molecular structures were further supported by the ${ }^{13} \mathrm{C}-\mathrm{NMR}$ spectra, which provided the number and types of carbons in the compounds, and the HR-MS spectra, which provided the compounds' molecular masses. These values showed complete agreement with the assigned molecular structures $[12,13,15]$.

\section{Anti-inflammatory and antioxidant activity}

The synthesized compounds (2a-2d) were evaluated for antiinflammatory activity using the inhibition of heat-induced albumin denaturation method. The decline in the test compounds' absorbance, with respect to the control, indicated protein stabilization. Denaturation of protein in vivo is one cause of inflammation; indeed, denaturation in certain rheumatic and arthritic diseases stimulates autoantigen production, which, in turn, drives inflammation [16]. Several anti-inflammatory drugs can inhibit heat-induced albumin denaturation. Therefore, agents inhibiting protein denaturation are worthwhile candidates for anti-inflammatory drugs $[17,18]$. The compounds showed moderate-to-high inhibition of heat-induced albumin denaturation, which was expressed as $\mathrm{IC}_{50}$ values in the range of 1.93-32.75 $\mu \mathrm{M}$ (Table 1 and Fig. 2). In this series, compound 2d, containing the dimethylamine Mannich base moiety, exhibited the most potent activity $\left(\mathrm{IC}_{50}=1.93 \mu \mathrm{M}\right)$. $2 \mathrm{~d}$ 's activity was comparable to diclofenac sodium $\left(\mathrm{IC}_{50}=1.53 \mu \mathrm{M}\right)$, four-fold higher than curcumin $\left(\mathrm{IC}_{50}=8.43 \mu \mathrm{M}\right)$, and 29 -fold higher than the parent compound, $(2 E, 6 E)$ 2-[(4-hydroxy-3-methoxyphenyl)methylidene]-6-(phenylmethylidene) cyclohexan-1-one (1) $\left(\mathrm{IC}_{50}=56.29 \mu \mathrm{M}\right)$. A previous study reported that the morpholine Mannich base derivative of AMAC compound 1 exhibited anti-inflammatory activity with $\mathrm{IC}_{50}=41.11 \mu \mathrm{M}$ [9]. This result is consistent with the results of another study on the introduction of Mannich bases into ibuprofen [19]. Compound 2d should be considered for further study to investigate its action mechanism and toxicity.

The synthesized compounds' (2a-d) antioxidant activities evaluated with the DPPH free radical scavenging assay. This method is fast and 
Table 1: Anti-inflammatory activity and antioxidant activity of the synthesized compounds (2a-d)

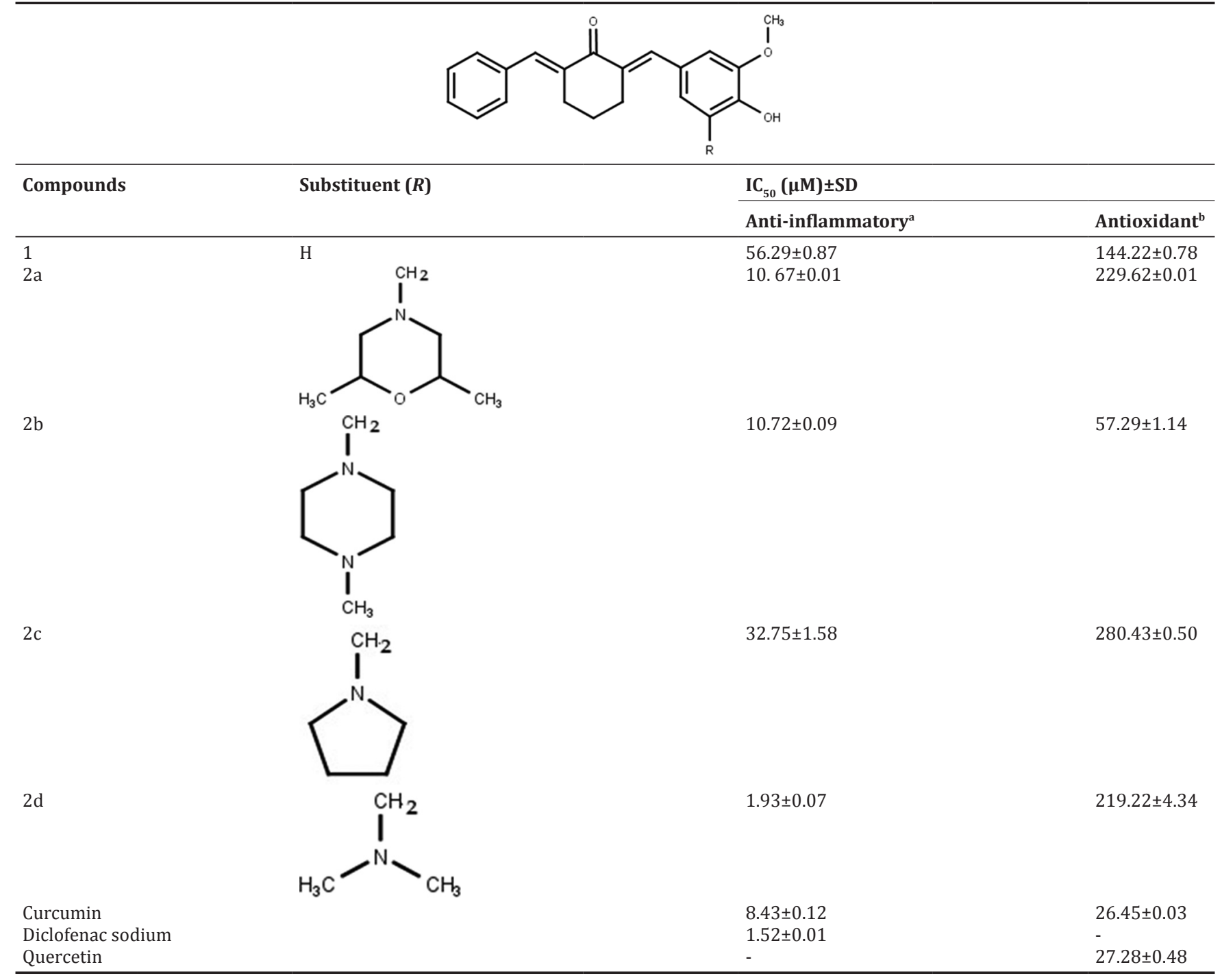

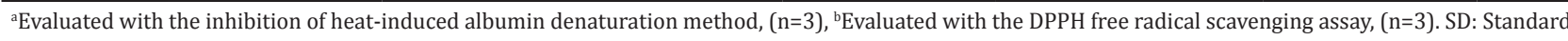
deviation, DPPH: 2,2-diphenyl-2-picrylhydrazyl

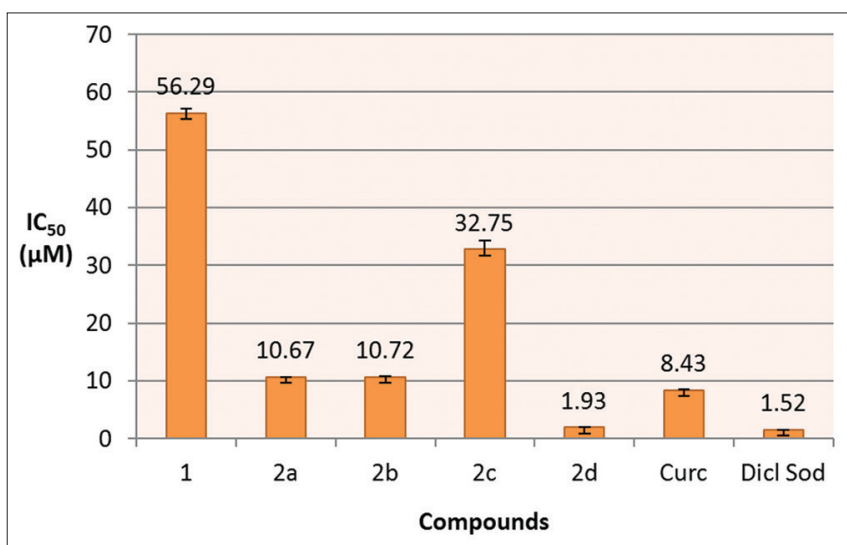

Fig. 2: The inhibition of heat-induced bovine serum albumin denaturation ( $\mathrm{IC}_{50}$ ) by the Mannich base derivatives of

(2E,6E)-2-[(4-hydroxy-3-methoxyphenyl)methylidene]-6(phenylmethylidene)cyclohexan-1-one (compounds 2a-d). Data represented as mean \pm standard deviation $(n=3)$ uncomplicated, ensuring a reliable result. Furthermore, the free radical scavenging approach is suitable with the test compounds' antioxidant mechanisms because they are phenolic compounds [20]. The compounds showed low-to-moderate DPPH free radical scavenging activity, which was expressed as $\mathrm{IC}_{50}$ values in the range of 57.29-280.43 $\mu \mathrm{M}$ (Table 1 and Fig. 3). In this series, the compound $2 \mathrm{~b}$, containing the pyrrolidine Mannich base moiety, was found to have the highest activity compared to the other three test compounds. It showed moderate activity $\left(\mathrm{IC}_{50}=57.29 \mu \mathrm{M}\right.$ ) compared to that of quercetin $\left(\mathrm{IC}_{50}=27.28 \mu \mathrm{M}\right)$ and curcumin $\left(\mathrm{IC}_{50}=26.45 \mu \mathrm{M}\right)$. A previous study reported that the morpholine Mannich base derivative of AMAC (compound 1) exhibited antioxidant activity with $\mathrm{IC}_{50}=229.20 \mu \mathrm{M}$ [9]. In our study, the other three Mannich base derivatives of compound 1 exhibited lower antioxidant activity than that of the parent compound (AMAC, 1) $\left(\mathrm{IC}_{50}=144.22 \mu \mathrm{M}\right)$. This result is inconsistent with our previous study on the Mannich base derivatives of dehydrozingerone (DHZ), which indicated that most of the compounds' Mannich bases exhibited higher free radical scavenging activity than DHZ [21]. In curcumin analogs, electron-donating substituents at ortho positions relative to the phenol groups enhance antioxidant activity, while bulky alkyl substituents inhibit it [22,23]. Mannich bases can also enhance or lower cyclovalone's free radical activity: the higher the basicity of 


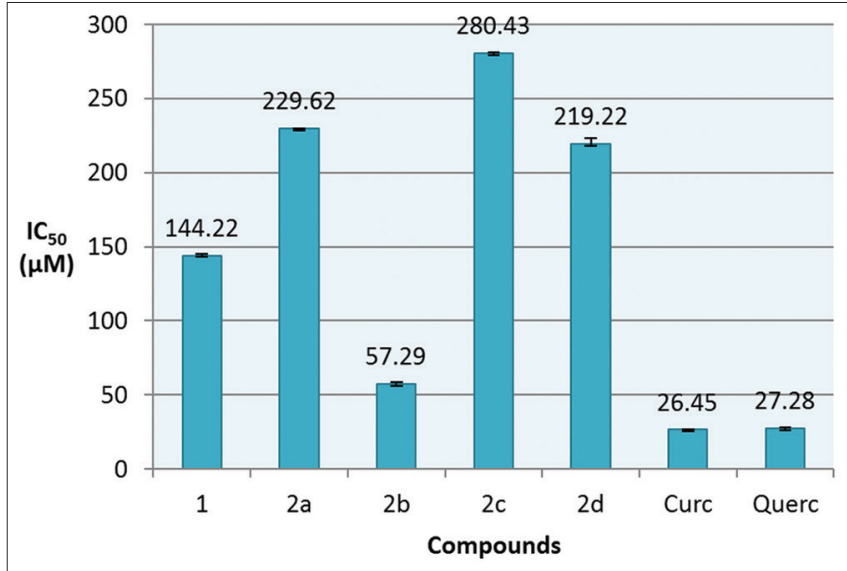

Fig. 3: The free radical scavenging activity $\left(\mathrm{IC}_{50}\right)$ of the Mannich base derivatives of $(2 E, 6 E)-2$-[(4-hydroxy-3-methoxyphenyl) methylidene]-6-(phenylmethylidene)cyclohexan-1-one (compounds 2a-d). Data represented as mean \pm standard deviation $(n=3)$

the nitrogen atom of the Mannich base derivative of cyclovalone, the higher the DPPH free radical scavenging activity of the compound [14]. However, this relationship was not observed for compounds 2a-d.

\section{CONCLUSION}

A series of four novel Mannich bases derivatives (compounds 2a-d) of one AMAC $(2 E, 6 E)-2-(\{4-h y d r o x y-3-m e t h o x y p h e n y l\} m e t h y l i d e n e)-6-$ (phenylmethylidene)cyclohexan-1-one, was successfully synthesized. The compounds' anti-inflammatory and antioxidant activities were evaluated using the inhibition of heat-induced albumin denaturation method and the DPPH free radical scavenging assay, respectively. All synthesized compounds (2a-d) showed moderate-to-high antiinflammatory activity and low-to-moderate antioxidant activity. Compound $2 \mathrm{~d}$, containing the dimethylamine Mannich base moiety, showed the highest anti-inflammatory activity, comparable to that of diclofenac sodium. This compound should be studied further to investigate its action mechanism and its toxicity.

\section{ACKNOWLEDGMENT}

The authors are grateful to the Directorate of Research and Community Services, Directorate of Higher Education of the Ministry of Research, Technology, and Higher Education of the Republic of Indonesia, for the financial support of this research and to Laboratory of Organic Chemistry, Chemistry Study Program, Faculty of Mathematics and Natural Science, Bandung Institute of Technology, Bandung, Indonesia, for recording NMR and mass spectral data.

\section{CONFLICT OF INTEREST}

The authors declare no conflict of interest.

\section{REFERENCES}

1. Lal J, Gupta SK, Thavaselvam D, Agarwal DD. Synthesis and pharmacological activity evaluation of curcumin derivatives. Chin Chem Let 2016;27:1067-72.

2. Anand P, Thomas SG, Kunnumakkara AB, Sundaram C, Harikumar KB, Sung B, et al. Biological activities of curcumin and its analogues (Congeners) made by man and mother nature. Biochem Pharmacol 2008;76:1590-611
3. Zhang Y, Zhao L, Wu J, Jiang X, Dong L, Xu F, et al. Synthesis and evaluation of a series of novel asymmetrical curcumin analogs for the treatment of inflammation. Molecules 2014;19:7287-307.

4. Zhao C, Liu Z, Liang G. Promising curcumin-based drug design: Mono-carbonyl analogues of curcumin (MACs). Curr Pharm Des 2013;19:2114-35.

5. Lamperti M, Maspero A, Tønnesen HH, Bondani M, Nardo L. Elucidation of the relationships between H-bonding patterns and excited state dynamics in cyclovalone. Molecules 2014;19:13282-304

6. Zhang Y, Jiang X, Peng K, Chen C, Fu L, Wang Z, et al. Discovery and evaluation of novel anti-inflammatory derivatives of natural bioactive curcumin. Drug Des Devel Ther 2014;8:2161-71.

7. Mohd Aluwi MFF, Rullah K, Yamin BM, Leong SW, Abdul Bahari MN, Lim SJ, et al. Synthesis of unsymmetrical monocarbonyl curcumin analogues with potent inhibition on prostaglandin E2 production in LPS-induced murine and human macrophages cell lines. Bioorg Med Chem Lett 2016;26:2531-8.

8. Li Q, Chen J, Luo S, Xu J, Huang Q, Liu T, et al. Synthesis and assessment of the antioxidant and antitumor properties of asymmetric curcumin analogues. Eur J Med Chem 2015;93:461-9.

9. Putri TN, Bachtiar A, Hayun H. Synthesis, antioxidant, and antiinflammatory activity of morpholine mannich base of AMACs ((2E, 6E)-2-(\{4-hydroxy-3-[morpholin-4-yl-)methyl]phenyl $\}$ methylidene)(phenylmethylidene)cyclohexan-1-one) and its analogs. J App Pharm Sci 2018;8:19-25.

10. Bala S, Sharma N, Kajal A, Kamboj S, Saini V. Mannich bases: An important pharmacophore in present scenario. Int $\mathrm{J}$ Med Chem 2014;2014:1-15.

11. Prasetyaningrum PW, Bahtiar A, Hayun H. Synthesis and antiproliferative activity of diethylamine mannich base of asymmetrical mono-carbonyl curcumin analogs against HeLa cell lines. Sci Pharm 2018;86:25

12. Untung J, Iskandarsyah I. Hayun, H. 2-[(2,6-Dimethylmorpholin-4-yl) methyl]-4-[(E)-2-\{3-[(E)-2-\{3-[(2,6-dimethylmorpholin-4-yl)methyl]4-hydroxy-5-methoxyphenyl $\}$ ethenyl]-1H-pyrazol-5-yl ethenyl]-6methoxyphenol. Molbank 2017;3:M949.

13. Hayun H, Jatmika C, Maswati EM, Salim S, Fajriawan AA, Nareswara $\mathrm{AD}$, et al. Synthesis and free radical scavenging activities of di-mannich bases of cyclovalone derivatives. Orient $\mathrm{J}$ Chem 2017;33:2742-57

14. Aksoy L, Kolay E, Ağılönü Y, Aslan Z, Kargıŏglu M. Free radical scavenging activity, total phenolic content, total antioxidant status, and total oxidant status of endemic Thermopsis turcica. Saudi J Biol Sci 2013;20:235-9.

15. Silverstein RM, Webster FX, Kiemle DJ. Spectrometric Identification of Organic Compounds. $7^{\text {th }}$ ed. New York, USA: John Wiley and Sons, Inc.; 2014.

16. Umapathy E, Ndebia EJ, Meeme A, Adam B, Menziwa P, Nkeh-Chungag BN, et al. An experimental evaluation of Albuca setosa aqueous extract on membrane stabilization, protein denaturation and white blood cell migration during acute inflammation. J Med Plants Res 2010;4:789-95.

17. Jagtap VA, Agasimundim YS, Jayachandran E, Sathe BS In vitro anti-inflammatory activity of 2-amino-3-(substituted benzylidinecarbohydrazide)-4,5,6,7- tetrahydrobenzothiophenes. J Pharm Res 2011:4:378-9.

18. Chandra S., Chatterjee P, Dey P, Bhattacharya S. Evaluation of in vitro anti-inflammatory activity of coffee against the denaturation of protein. Asian Pac J Trop Biomed 2012;2:S178-80.

19. Sujith KV, Rao JN, Shetty P, Kalluraya B. Regioselective reaction: Synthesis and pharmacological study of mannich bases containing ibuprofen moiety. Eur J Med Chem 2009;44:3697-702.

20. Dontha S. A review on antioxidant methods. Asian J Pharm Clin Res 2016;9:14-32.

21. Hayun H, Arrahman A, Purwati EM, Yanuar A, Fortunata F, Suhargo F, et al. Synthesis, anti-inflammatory, and antioxidant activity of mannich bases of dehydrozingerone derivatives. J Young Pharm 2018;10:s6-10.

22. Zheng QT, Yang ZH, Yu LY, Ren YY, Huang QX, Liu Q, et al. Synthesis and antioxidant activity of curcumin analogs. J Asian Nat Prod Res 2017; 19:489-503.

23. Itokawa H, Shi Q, Akiyama T, Morris-Natschke SL, Lee KH. Recent advances in the investigation of curcuminoids. Chin Med 2008;3:11. 